\title{
Study of precipitation chemistry over an industrial city
}

\author{
D. Banerjee \\ Department of Environment and Water Management, Banwarilal Bhalotia College, Asansol, \\ West Bengal, India
}

Received 4 December 2007; $\quad$ revised 18 January 2008; accepted 2 March 2008; $\quad$ available online 1 June 2008

\begin{abstract}
The growing trend of industrialization has marked impact on the atmospheric chemistry around the globe. Such impacts are also predicted for developing countries like India. Acid precipitation due to secondary pollutants is one of them. The present investigation was conducted with an aim of studying the precipitation chemistry over Asansol city, India during the monsoon season. The rain water samples, collected on event basis during the period of June to September 2006, were analyzed for $\mathrm{HCO}_{3}^{-}, \mathrm{Cl}^{-}, \mathrm{SO}_{4}{ }^{2-}, \mathrm{NO}_{3}^{-}, \mathrm{NH}_{4}^{+}, \mathrm{K}^{+}, \mathrm{Na}^{+}, \mathrm{Mg}^{2+}, \mathrm{Ca}^{2+}$ and $\mathrm{pH}$ using standard procedures. The study revealed that the precipitation was alkaline in nature with mean $\mathrm{pH}$ value of 6.08. Dominant anion in rain water samples was $\mathrm{HCO}_{3}^{-}(36 \%)$, whereas $\mathrm{Ca}^{2+}$ was highest among the cations $(53 \%)$. The observed acidic events, based on $\mathrm{pH}$ value, were only $17 \%$, indicating the alkaline components effectively neutralize rain water over the area. This was also supported by the total alkaline to acid ion ration of 1.05 . The ratio of $\left(\mathrm{NO}_{3}{ }^{-}+\mathrm{Cl}^{-}\right)$and $\mathrm{SO}_{4}{ }^{2-} \mathrm{Was}^{-}$ $>1$, indicating that acidic properties were influenced by $\mathrm{HNO}_{3}$ and $\mathrm{HCl}$. In the ratio between $\left(\mathrm{Ca}^{2+}+\mathrm{NH}_{4}^{+}\right)$and $\left(\mathrm{NO}_{3}{ }^{-}+\mathrm{SO}_{4}{ }^{2-}\right)$, values $>1$ were obtained, indicating significant alkaline influence, which effectively prevented acid depositions in the area.
\end{abstract}

Key words: Rain water, ionic character, acid rain, air pollution, urban area

\section{INTRODUCTION}

The clean air mass of the troposphere, the lower most layer of the atmosphere, collects both natural and anthropogenic products as it moves across the surface of the earth. While natural products include emissions from volcanic activity, sea salt sprays, dust storms and forest fires, the man made emission sources are much varied and more detrimental. In an urban area these manmade sources include automobile emission, industrial operations, fuel combustion, open burning, bacterial decomposing of nitrogenous materials, municipal waste disposal, etc. Pollutants that enter directly in to the atmosphere are termed primary pollutants, where as those formed by reaction of the primary pollutants with each other or other components of the air are called secondary pollutants. The latter products then travel in the direction of wind flow and return to earth as particles, droplets or chemicals dissolved in precipitation, among which rain water is most common. The chief contaminants of rain water, which has a natural $\mathrm{pH}$ of 5.6, include $\mathrm{SO}_{2}, \mathrm{SO}_{3}$ and NOx among others. They dissolve as strong mineral acids like sulphuric acid and nitric acid in the rain water

$\bar{X}$ *Corresponding Author Email: profdibyendu@rediffmail.com Tel./Fax: 03412255181 and bring down the $\mathrm{pH}$ to less than 5.6, causing severe impact on the natural and urban environment. The concentrations of these acids are too weak to cause direct burn, but they produce other effects and cause serious ecological instability depending on a variety of biological, chemical and meteorological factors in soil, water bodies, vegetation, animals and buildings and other man made structures. It causes not only serious health effects, but also economic loses and disrupt ecosystem functions.

In India the total Sulphur emissions are expected to rise from 4,400 kilotons in 1990 to 10,900 kilotons in 2010 and 18,500 kilotons in 2020. Instances of acid rain are increasing and mostly being reported from metropolitan area (Anjaneyulu, 2002). Acid Rain studies have been carried out by Indian Institute of Tropical Meteorology for the last three decades. In order to study the spread of acid rain over India, the $\mathrm{pH}$ values and precipitation chemistry have been studied by various authors over the years. In India works that can be cited include those by Khemani et al., 1985, 1989 and 1994, working in areas of various factors that affect the precipitation chemistry as well as its spread over the India subcontinent. Work done by Satsangi et al., 
1998; Tiwari et al., 2004, included analysis of rain water specifically over rural and semi-arid locations in India and thus identifying factors that are exclusive to rural India influencing precipitation chemistry. Saxena et al., 1996, Srinivas et al., 1999; Singh et al., 2007 carried out similar investigations in urban cities of India, namely Agra, Dhanbad, Hyderabad-Secundrabad respectively. Kulshrestha et al., 1995 and 1996 worked along similar areas mostly in the urban New Delhi locations and demonstrated high influence of anthropogenic factors on the precipitation chemistry with lowering of $\mathrm{pH}$ values to uncomfortable ranges. Kulshrestha et al., 2003 also carried out similar studies in cities of southcentral India and identified similar factors that lead to acid rainfall in these locations. Mahadevan et al., 1984 and 1989 carried out chemical analysis of precipitation in both industrial-urban areas as well as in rural-arid areas of India. Naik et al., 1985, 1988 and 2002 analysed precipitation chemistry at representation and diverse locations including Hill station, Rural India and Industrial-urban area. The studies identified Mumbaiindustrial region as having significant acid precipitation and low $\mathrm{pH}$ range in rainfall samples. Mukhopadhyay et al., 1992; Parashar et al., 2001 analysed rainfall samples across the Indian subcontinent and identified hotspots of acid rainfall. The associated areas were significantly of Industrial-urban locations. Other similar works carried out by in the Indian subcontinent include those by Rao et al., 1995; Kumar et al., 2002; Pillai et al., 2001. Their study area included sensitive silent valley forested areas, sub-urban arid regions and urban-industrial town of Pune.

These studies revealed that the $\mathrm{pH}$ values were higher $(\mathrm{pH}>7.0)$ in the north and north-west parts of India while they were slightly lower ( $6.0 \mathrm{~d}$ " $\mathrm{pH}$ d"7.0) in the northeastern and southern parts of India. Work done by Balachandran et al. (2001) in Delhi during the monsoon period, reported $\mathrm{pH}$ values higher than 5.6. Work done by Granat et al. (2001) in the north east India showed that weighted mean concentrations of $\mathrm{H}^{+}$and $\mathrm{HCO}^{--}$were almost equal. Shrestha et al., 2002 analysed the precipitation chemistry including aerosol characteristics over the isolated areas of Himalayan mountain range at Nepal. Comparable research investigations have also be carried out else where by Clarke et al., 1987, Masamichi et al., 2005; Mphepya et al., 2004, Primerano et al., 1998; Williams et al., 1998 investigated the industrial dust and particulate factors that influence the characteristics of urban areas.
Asansol geographically located between latitude: $23^{\circ} 40^{\prime} 48^{\prime \prime}$ to $23^{\circ} 40^{\prime} 68^{\prime \prime}$ North and longitude: $86^{\circ} 58^{\prime} 48^{\prime \prime}$ to $86^{\circ} 40^{\prime} 98^{\prime \prime}$ East is situated in Burdwan district of West Bengal state. It is urban agglomerate with an area of $127 \mathrm{Km}^{2}$ and a population density of about 3737 individuals per $\mathrm{Km}^{2}$. The city falls in the eastern, industrial belt of India. Industries present in and around the city include iron and steel, cement, distillery, silicate, soap and detergent, ceramics, engineering, paint, food processing, flour mills, etc. The city forms a part of the Raniganj-Coal field area. The industrial and mining operations contribute considerably to the atmospheric pollution along with vehicular emission and domestic burnings. The National Highway and The Grand Trunk Road passing through the city, transport massive traffic and consequently account for heavy discharge to the atmosphere. Emission from the vehicular movement and the Iron and Steel works are the chief polluting sources for this area (Banerjee etal., 2005).

The climatic pattern is of typical tropical monsoon type with the year subdivided into three major seasons, namely summer, south-west monsoon and winter. During summers the mean max. temperature is $38.2{ }^{\circ} \mathrm{C}$ where as the mean min. temperature is $24.3^{\circ} \mathrm{C}$. The monsoon season starts during end of June with temperature ranging from $29.1{ }^{\circ} \mathrm{C}$ to $34.4^{\circ} \mathrm{C}$. By October, the mean temperature falls gradually marking the onset of the winter season. The maximum humidity, observed during the monsoon season, has mean value of $85 \%$. The minimum humidity in Pre-monsoon (April-June) is $27 \%$. Annual rainfall obtained from the nearest meteorological office of IMD (Indian Meteorological Department) over a period of 10 years indicates average annual rainfall to be about $1500 \mathrm{~mm}$. Nearly $80 \%$ of the rainfall is received during monsoon season. The monsoon starts in end of June and continues till September.

The maximum amount of rainfall is received in July and the maximum rainy days occur in July. Wind is normally light to moderate in the area in the premonsoon season. During early monsoon wind speed is very high. The predominant wind direction during the rainy season (monsoon) is South West followed by West. The major objectives of the study was to appraise the chemical composition of rain water during the monsoon period and observe if acid rain fall events, if any, are occurring due to anthropogenic or natural processes. 


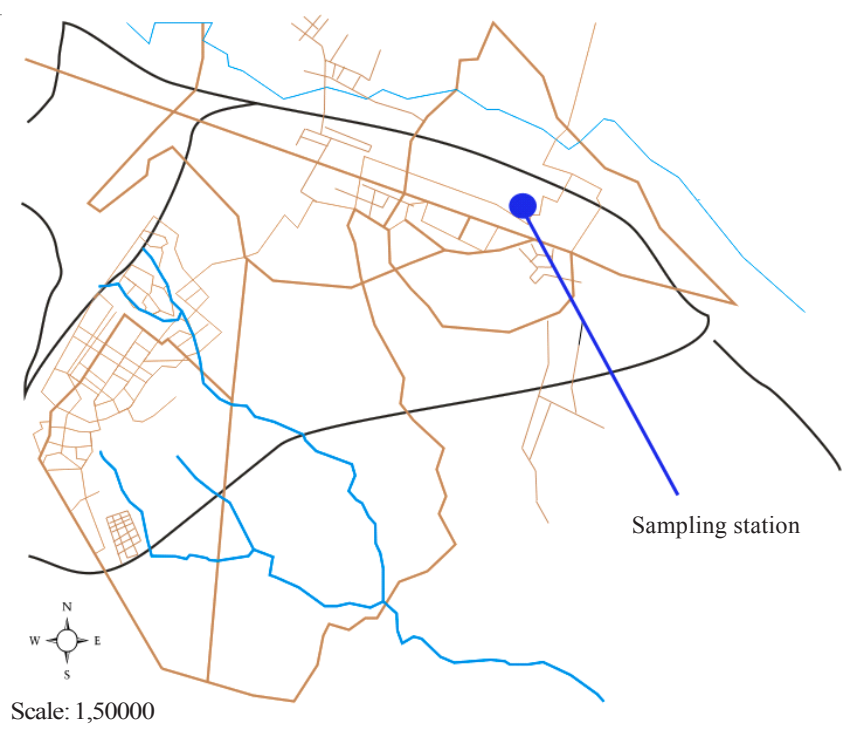

Fig. 1: Map showing study area and sampling station

\section{MATERIALS AND METHODS}

Samples of rainwater were collected on the open roof (about $10 \mathrm{~m}$ from the ground) during the monsoon season, from $2^{\text {nd }}$ June 2006 to 29 September 2006 on an event basis. The location of study area is shown in Fig. 1. The sampling station was located in B.B. College, Asansol in the Burdwan District, West Bengal State of India. The site is about 200 meters from the busy and Grand Truck Road is located in a residential zone. Industries and mining activities are located at distances of $1.5-2 \mathrm{~km}$ away, which contributes heavily to the atmospheric load of pollutants in this city. Collected sampled were analysed in the Department of Environment and Water Management, B.B. College, Asansol. Sampling was conducted as per guidelines of Tiwari et al. (2004) and analysis of rain water was as per APHA (APHA, 1998). Rain gauge, previously washed with demonized water, was used to collect the sample on $24 \mathrm{~h}$. basis. Rain gauge and collecting system were washed during morning and evening throughout the study period to avoid dry deposition, although contamination due to dust fall had to be taken into account. All the samples were filtered through Whatman-41 filter paper before analysis. Samples were removed at 10:30 h. for night time rainfall events and 17:00 hours for day time rainfall. The concentrations of cations, namely, $\mathrm{Ca}^{2+}$ and $\mathrm{Mg}^{2+}$ were estimated by Titrimetric method; $\mathrm{Na}^{+}$and $\mathrm{K}^{+}$by Flame photometric method and $\mathrm{NH}_{4}^{+}$by Spectrophotometric method.
Chloride $\left(\mathrm{Cl}^{-}\right)$was estimated using Titrimetric method; $\mathrm{SO}_{4}{ }^{2-}$ and $\mathrm{NO}_{3}^{-}$by Spectrophotometric method. $\mathrm{pH}$ values were determined with digital $\mathrm{pH}$ meter. All instruments/systems were properly standardized and calibrated ahead of every estimation. $\mathrm{HCO}_{3}^{-}$was calculated from alkalinity values of rain water samples. All reagents, standard solutions were prepared from AR grade chemicals and de-ionised distilled water. The meteorological data and previous climatic norms of the study region were obtained from IMD, Pune.

\section{RESULTS AND DISCUSSION}

The mean ionic composition and $\mathrm{pH}$ values, along with the minimum and maximum value of the rain water samples, collected and analyzed during the June 2006 - Septrmber 2006 South-West Monsoon period at Asansol are given in Table 1. Results based on similar studies in India are given in Table 4 for comparison. Fig. 2 shows the frequency distribution of $\mathrm{pH}$ values of rain water samples during the study period. The relative percentage contribution of different ions to the total ionic content is Fig. 3. The scatter diagrams showing association between $\left(\mathrm{NO}_{3}+\mathrm{Cl}\right) \mathrm{vs}_{4} \mathrm{SO}_{4}$ and $\left(\mathrm{NH}_{4}+\mathrm{Ca}\right)$ vs $\left(\mathrm{NO}_{3}+\mathrm{SO}_{4}\right)$ is shown in Fig. 4. The correlation matrix for different ions in rain water samples is given in Table 2 and ratios of selected species with sodium is given in Table 3. The $\mathrm{pH}$ of natural precipitation is 5.65 , a value created by equilibration of atmosphere $\mathrm{CO}_{2}$ with precipitation (Naik et al., 2002). 
In the present study the $\mathrm{pH}$ varied between 5.02 and 6.93 (mean 6.08 \pm 0.45 ), demonstrating acidic to alkaline range of the rainwater samples. The $\mathrm{pH}$ profile showed that out of the total rainfall event $17 \%$ were acidic $(<5.65)$, whereas $83 \%$ accounted for alkaline rainwater. The $\mathrm{pH}$ frequency distribution for all samples were estimated by assigning them into nine categories (Naik et al., 2002) ranging between 4.0 to 8.0 with 0.5 increment. The $\mathrm{pH}$ data was plotted for the different classes and shown as Fig. 2. Samples with low pH i.e. < 5.0 were not observed, indicting absence of very acidic rainwater. Similarly samples with $\mathrm{pH}$ values higher than 7.0 were also not recorded. The $\mathrm{pH}$ ranged in the mid values with $10 \%$ samples in the $\mathrm{pH}$ range of $5.5 ; 25 \%$ in the 6.0 and 7.0 and highest $40 \%$ in the 6.5 group. This is close to the Indian average rain water $\mathrm{pH}$ of 6.5 . The results demonstrated that strong influence of strong acids was lacking in the rain water samples, where as alkaline components over the area played vital part in keeping the precipitation in the neutral to alkaline category in most cases. As shown in Table 3, the $\mathrm{pH}$ values had significant positive correlation with cationic components like $\mathrm{Na}^{+}, \mathrm{Mg}^{2+}$ and $\mathrm{NH}_{4}^{+}$. The chief acidic components were $\mathrm{Cl}^{-}$and $\mathrm{NO}_{3}^{-}$, while the presence of $\mathrm{SO}_{4}{ }^{2-}$ was less (Fig. 4b). From Table 1 and Fig. 3 it was observed that the dominant ion species in the rainwater sample was Calcium (28\%), followed by Carbonate (17\%) and Chloride (16\%). The ionic abundance in the rain water was seen to follow the trend: $\mathrm{Ca}^{2+}>\mathrm{HCO}_{-}{ }_{3}^{-}>\mathrm{Cl}^{-}>\mathrm{SO}_{4}{ }^{2-}>\mathrm{Mg}^{2+}>\mathrm{NH}_{4}^{+}>\mathrm{Na}^{+}$ $>\mathrm{NO}_{3}>\mathrm{K}^{+}$. The Alkaline components (Cation), namely, $\mathrm{Ca}^{2+}, \mathrm{Mg}^{2+}, \mathrm{Na}^{+}, \mathrm{K}^{+}$and $\mathrm{NH}_{4}^{+}$contributes about $51.2 \%$ of the total ion strength, where as acidic components (Anion) comprising of $\mathrm{SO}_{4}{ }^{2-} \mathrm{Cl}^{-}, \mathrm{NO}_{3}{ }^{-}, \mathrm{HCO}_{3}{ }^{-}$was $48.7 \%$.

The precipitation chemistry is dependent on its acidic and alkaline ions composition and the acidic effect neutralization capacity on the alkaline species like $\mathrm{Ca}^{2+}, \mathrm{Mg}^{2+}, \mathrm{Na}^{+}, \mathrm{K}^{+}$and $\mathrm{NH}_{4}^{+}$(Singh et al., 2007). The anionic and cationic composition of the rain water is given in Fig. 4. Among the anions the dominant was $\mathrm{HCO}_{3}^{-}$, contributing $36 \%$ to this group and $17 \%$ to the total ions composition. This was followed by $\mathrm{Cl}^{-}(33 \%)$, $\mathrm{SO}_{4}{ }^{2-}(23 \%)$ and $\mathrm{NO}_{3}{ }^{-}(8 \%)$. In the cation category $\mathrm{Ca}^{2+}$ was dominant, contributing $53 \%$ in the group and 28 $\%$ to total ions chemistry. This was followed by $\mathrm{Mg}^{2+}$ $(18 \%), \mathrm{NH}_{4}^{+}(17 \%), \mathrm{Na}^{+}(10 \%)$ and $\mathrm{K}^{+}(2 \%)$. These components are generally derived from particulates washed down by the precipitation mainly in the monsoon period. After the removal of such species, the rain water turns more acidic during the late monsoon phase with the acidic components dominating.

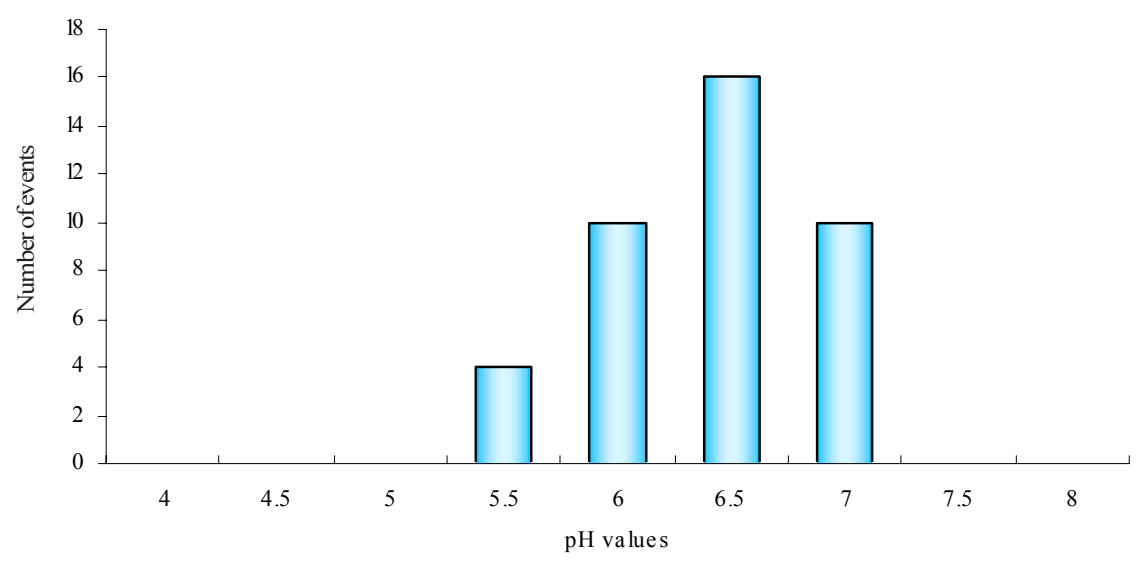

Fig. 2: Frequency distribution of $\mathrm{pH}$ values of rain water samples over Asansol during 2006 monsoon

Table 1: Statistical analysis of chemical composition of rainwater over Asansol during 2006 monsoon

\begin{tabular}{lllllllllll}
\hline & $\mathrm{pH}$ & $\mathrm{K}$ & $\mathrm{Na}$ & $\mathrm{Ca}$ & $\mathrm{Mg}$ & $\mathrm{Cl}$ & $\mathrm{SO}_{4}$ & $\mathrm{NO}_{3}$ & $\mathrm{HCO}_{3}$ & $\mathrm{NH}_{4}$ \\
\hline S.D. & 0.45 & 1.71 & 8.21 & 25.26 & 5.11 & 25.04 & 22.54 & 3.71 & 10.45 & 6.61 \\
Min. & 5.02 & 1.14 & 7.36 & 6.58 & 23.49 & 11.16 & 9.04 & 9.00 & 37.37 & 21.25 \\
Mean & 6.08 & 4.18 & 20.09 & 106.86 & 36.72 & 63.07 & 44.22 & 16.12 & 68.38 \\
Max. & 6.93 & 8.81 & 33.84 & 141.68 & 44.44 & 88.11 & 84.40 & 25.07 & 84.61 & 46.02 \\
\hline
\end{tabular}

All units in $\mu \mathrm{eq} / \mathrm{L}$, except $\mathrm{pH}$ 
The higher concentration of $\mathrm{Ca}^{2+}$, an important acid neutralizing species, could be contributed in the form of Calcite $\left(\mathrm{CaCO}_{3}\right.$, Dolomite $\left(\mathrm{CaCO}_{3}, \mathrm{MgCO}_{3}\right)$, etc, in the soil blown up by wind. Other major sources of $\mathrm{Ca}$, i.e. Cement and Iron and Steel industries are present within and around the study area in good number. High concentration of $\mathrm{NH}_{4}^{+}$may be attributed to nearby agricultural and local 'Khatals' (diary) inside the city, where bacterial decomposition of urine and 'cow dung' occur openly. The presence of higher concentration of these species in the rainwater neutralizes the acidic components and prevents acid deposition in the area. This was also proved by the observed $\mathrm{pH}$ value range of $5.02-6.93$ (mean $6.08 \pm 0.45$ ), with majority of the samples having $\mathrm{pH}$ near the 6.5 mark. Among the anions $\mathrm{HCO}_{3}^{-}$was highest, followed by $\mathrm{Cl}^{-}(33 \%)$.

The ration of $\left(\mathrm{NO}_{3}+\mathrm{Cl}\right) /\left(\mathrm{SO}_{4}\right)$ and $\left(\mathrm{NH}_{4}+\mathrm{Ca}\right) /$ $\left(\mathrm{NO}_{3}+\mathrm{SO}_{4}\right)$ was estimated, since these ions determine the acid producing and acid neutralization capacity of the precipitation to a huge extent. The balance among these species dictates the acidic or basic nature of the rainwater. The scatter plots among these species are given in Fig. 4. The ratio of $\left(\mathrm{NH}_{4}+\mathrm{Ca}\right):\left(\mathrm{NO}_{3}+\mathrm{SO}_{4}\right)$ varied between 0.88 to 9.13 (mean $2.76 \pm 1.52$ ) and the scatter plot in Fig. 4a shows that all points except one fell above the equiline, demonstrating that both $\mathrm{NH}_{4}$ and
$\mathrm{Ca}^{2+}$ appreciably neutralized the anions in the analyzed rain water samples. The ration of $\left(\mathrm{NO}_{3}+\mathrm{Cl}\right):\left(\mathrm{SO}_{4}\right)$, which indicates whether the acidity in rain water is contributed by $\mathrm{HNO}_{3} / \mathrm{HCl}$ or $\mathrm{H}_{2} \mathrm{SO}_{4}$ ranges from 0.64 to 8.08 with mean of $2.28 \pm 1.50$ (Singh et al., 2007). The bivariate plot in Fig. 4b, representing this association, showed that nearly all points are above the equiline, indicating that the acidity in the analyzed rain water samples is significantly influenced by $\mathrm{HNO}_{3}$ and $\mathrm{HCl}$ in the area. The total contribution of $\mathrm{NO}_{3}+\mathrm{Cl}$ ions is $41 \%$ and supports the ratio results. The high $\mathrm{Cl}^{-}$in the rain water samples, ranging from 6.58 to $141.68 \mu \mathrm{eq} / \mathrm{L}(106.86 \pm$ $25.26 \mu \mathrm{eq} / \mathrm{L}$ ) suggested significant contribution from seawater and also to some extent on industrial activities like chemical, silicate and refractory plants present in and around the study area. The $\mathrm{NO}_{3}^{-}$contribution was typically from road vehicles inside the city, which has evidenced an alarmingly high increase in vehicular population due to rapid development and urbanization in the area within a short period.

To collect information about association among the ionic species present in the rain water samples and to evaluate their likely sources a correlation matrix was prepared and the results are given in Table 3. Significant positive correlation was observed between $\mathrm{pH}$ and $\mathrm{Cl}^{\text {}}$, $\mathrm{NH}_{4}^{+}, \mathrm{NO}_{3}^{-}, \mathrm{Na}^{+}, \mathrm{SO}_{4}{ }^{2-}, \mathrm{HCO}_{3}{ }^{-}$and $\mathrm{Mg}^{2+}$, showing their
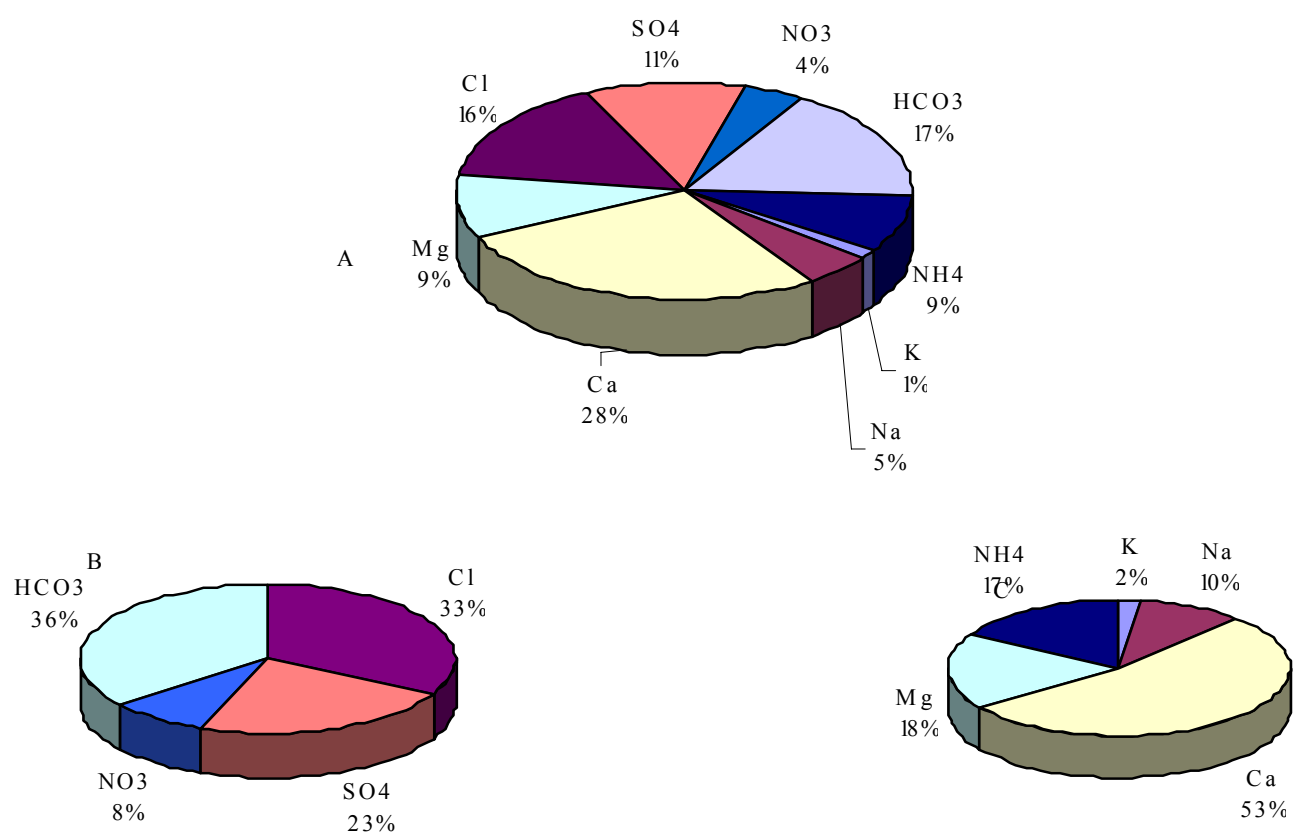

Fig. 3: Chemical composition of monsoon rainfall over Asansol city

A) All ionic composition B) Anionic contribution C) Cation contribution 
Banerjee, $D$
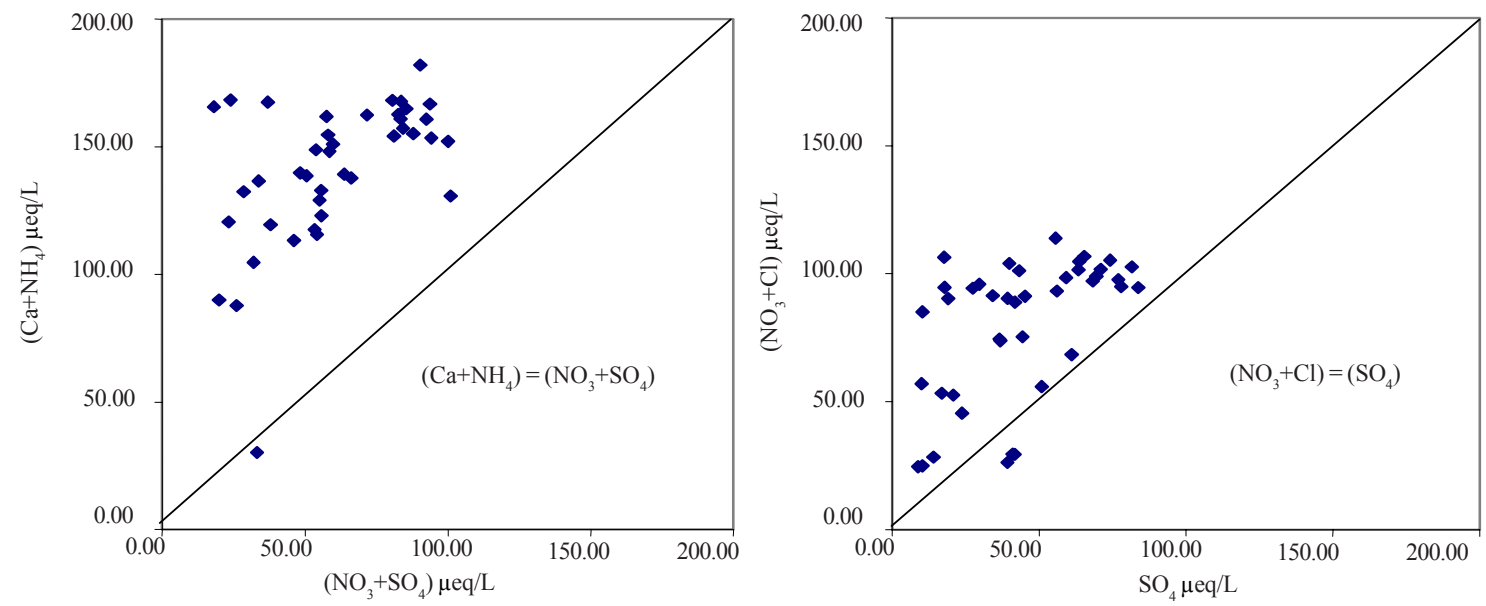

Fig. 4: Scatter plot diagram between $\mathrm{A})\left(\mathrm{NH}_{4}+\mathrm{Ca}\right)$ vs $\left(\mathrm{NO}_{3}+\mathrm{SO}_{4}\right)$ and $\left.\mathrm{B}\right)\left(\mathrm{NO}_{3}+\mathrm{Cl}\right)$ vs $\mathrm{SO}_{4}$ based on analysis of rain water sample over Asansol

influence on the acid-base nature on the rain water samples. Strong positive correlation was recorded amongst $\mathrm{NH}_{4}^{+}$with most of the other ions except $\mathrm{K}^{+}$ and $\mathrm{Ca}^{2+}$. The highest correlation $(\mathrm{r}=0.762)$ was observed with $\mathrm{NO}_{3}$, which suggested the significant presence of $\mathrm{NH}_{4} \mathrm{NO}_{3}$ in the area. The weak to moderate correlation among $\mathrm{Ca}^{2+}, \mathrm{Mg}^{2+}, \mathrm{K}^{-}$and $\mathrm{Na}^{+}$suggests that probably they have originated from different sources. The moderately strong correlation of $\mathrm{NO}_{3}$ with $\mathrm{SO}_{4}^{2-}$ suggests that probably they are mostly due to man made contribution and this is supported by the fact that the region is an industrial area with significantly high atmospheric pollutant load (Banerjee et al., 2005). Significant positive correlation is observed between $\mathrm{Na}$ and $\mathrm{Cl}^{-}(0.745), \mathrm{NO}_{3}^{-}(0.700)$ and $\mathrm{HCO}_{3}^{-}$ (0.529). The influence of the south-west monsoon on the rain chemistry was assessed by estimating the rations of $\mathrm{Na}$ with other ions and the results are shown in Table 3. The $\mathrm{Na} / \mathrm{Cl}$ ratio of 3.140 is many times higher than the seawater, indicating strong influence of the south-west wind brought over the Bay of Bengal. Some portion of the contribution may be through man made sources like industrial activity. The rations of other ions to Na showed similar trends, i.e. much higher than the seawater and it can be said the chemical makeup of rain water over Asansol was markedly influenced by the sea fraction.

The relative chemical analysis records of rain water studies done elsewhere in India with the present investigation in Asansol (Table 4) showed that $\mathrm{pH}$ value of rain water over Asansol was lower than the Indian average of 6.5 (Singh et al., 2007). The mean $\mathrm{pH}$ was lower than other areas like Gopalpura, Hyderabad,
Colaba, Alibag and Ballia, but was higher than that in Kalyan and Dhanbad. The concentration of $\mathrm{Na}$ and $\mathrm{Cl}$ were significantly lower than those recorded in the coastal belts of western India, namely Kalyan, Colaba and Alibagh.

The comparison of the chemical analysis of the present study with that of Dhanbad, situated about 65 km away, showed that although $\mathrm{Na}^{+}, \mathrm{NO}_{3}^{-}$and $\mathrm{NH}_{4}^{+}$ values are more or less closely related but other parameters varies significantly. The $\mathrm{pH}$ value of 5.3 in Dhanbad area is much lower than the 6.08 value recorded over Asansol. This may be because although both the areas have similar features, with Dhanbad being more industrialized, the anthropogenic contribution of the acid producing ions are less over Asansol. The mean value of $\mathrm{SO}_{4}{ }^{2-}$ and $\mathrm{NO}_{3}{ }^{-}$was comparable to most of the other areas. The values were less in comparison to those found in Hyderabad, Kolaba, Kalyan and Alibagh, since the congestion factor and heavy vehicular movement are extremely high in these cities.

The present investigation was conducted to evaluate the precipitation chemistry over Asansol during 2006 monsoon season. The rain water samples showed neutral to alkaline nature with mean $\mathrm{pH}$ value much higher than the reference value of 5.65. Frequency distribution of $\mathrm{pH}$ values established that $40 \%$ of rainfall events were in the 6.5 category, which is in accordance to the average Indian value. The major ion chemistry showed alkaline components influences were greater than the acidic types. The mean alkaline to acidic ratio was 1.05 . The dominant cation was $\mathrm{Ca}$, followed by $\mathrm{Mg}$ and $\mathrm{NH}_{4}$. Among the anions, $\mathrm{HCO}_{3}$ 
Table 2: Correlation between the major ions present in rain water samples in Asansol

\begin{tabular}{|c|c|c|c|c|c|c|c|c|c|c|}
\hline & $\mathrm{pH}$ & $\mathrm{K}$ & $\mathrm{Na}$ & $\mathrm{Ca}$ & $\mathrm{Mg}$ & $\mathrm{Cl}$ & $\mathrm{SO}_{4}$ & $\mathrm{NO}_{3}$ & $\mathrm{HCO}_{3}$ & $\mathrm{NH}_{4}$ \\
\hline $\mathrm{pH}$ & 1.000 & 0.237 & 0.658 & 0.228 & 0.550 & 0.699 & 0.564 & 0.672 & 0.554 & 0.680 \\
\hline $\mathrm{K}$ & & 1.000 & 0.151 & 0.226 & 0.378 & 0.150 & 0.274 & 0.358 & 0.392 & 0.473 \\
\hline $\mathrm{Na}$ & & & 1.000 & 0.352 & 0.391 & 0.745 & 0.476 & 0.700 & 0.529 & 0.590 \\
\hline $\mathrm{Ca}$ & & & & 1.000 & 0.627 & 0.354 & 0.387 & 0.413 & 0.059 & 0.394 \\
\hline $\mathrm{Mg}$ & & & & & 1.000 & 0.460 & 0.638 & 0.628 & 0.286 & 0.655 \\
\hline $\mathrm{Cl}$ & & & & & & 1.000 & 0.511 & 0.611 & 0.477 & 0.587 \\
\hline $\mathrm{SO}_{4}$ & & & & & & & 1.000 & 0.520 & 0.355 & 0.619 \\
\hline $\mathrm{NO}_{3}$ & & & & & & & & 1.000 & 0.461 & 0.762 \\
\hline $\mathrm{HCO}_{3}$ & & & & & & & & & 1.000 & 0.653 \\
\hline $\mathrm{NH}_{4}$ & & & & & & & & & & 1.000 \\
\hline
\end{tabular}

Table 3: Ratios of various ions with respect to Sodium in rain water samples

\begin{tabular}{lllll}
\hline & $\mathrm{Cl}: \mathrm{Na}$ & $\mathrm{Mg}: \mathrm{Na}$ & $\mathrm{K}: \mathrm{Na}$ & $\mathrm{Ca}: \mathrm{Na}$ \\
\hline Rainwater (present study) & 3.140 & 1.828 & 0.208 & 5.320 \\
Seawater & 1.160 & 0.227 & 0.022 & 0.044 \\
Tiwari et al & 1.320 & 0.810 & 0.560 & 0.125 \\
\hline
\end{tabular}

Table 4: Average Ionic concentrations $(\mu \mathrm{eq} / \mathrm{L})$ of rainwater at different geographical locations in India

\begin{tabular}{lllllllllllll}
\hline Location & Reference & Study period & $\mathrm{pH}$ & $\mathrm{K}$ & $\mathrm{Na}$ & $\mathrm{Ca}$ & $\mathrm{Mg}$ & $\mathrm{Cl}$ & $\mathrm{SO}_{4}$ & $\mathrm{NO}_{3}$ & $\mathrm{HCO}_{3}$ & $\mathrm{NH}_{4}$ \\
\hline Gopalpura & Satsangi et al. & 1998 & $6.1-7.4$ & 3 & 19 & 134 & 78 & 31 & 15 & 43 & - & 43 \\
Hyderabad & Srinivas et al. & 1999 & 6.34 & 8 & 38 & 41 & 20 & 73 & 30 & 29 & - & - \\
Kalyan & Naik et al. & $1994-95$ & 5.28 & 6 & 147 & 130 & 48 & 134 & 110 & 66 & - & 14 \\
Colaba & Naik et al. & $1994-95$ & 6.38 & 6 & 179 & 155 & 48 & 171 & 52 & 34 & - & 12 \\
Alibag & Naik et al. & $1994-95$ & 6.74 & 5 & 220 & 133 & 64 & 236 & 36 & 9 & - & 8 \\
Dhandad & Singh et al. & $2003-2005$ & 5.30 & 13.1 & 17.8 & 70.0 & 15.6 & 27.4 & 62.8 & 10.2 & - & 35.3 \\
Ballia & Tiwari et al. & 2004 & 6.31 & 3 & 6 & 40 & 5 & 8 & 37 & 16 & 18 & 58 \\
Asansol & (Present Study) & 2006 & 6.08 & 4 & 20 & 107 & 37 & 63 & 44 & 16 & 68 & 33 \\
\hline
\end{tabular}

was highest, followed by $\mathrm{Cl}$. Among the major acidic components $\mathrm{SO}_{4}$ was higher than $\mathrm{NO}_{3}$ by a factor of about 3 . In the total contribution $\mathrm{Ca}$ was the major ion, generated from dust derived fractions in the region. The dominant alkaline components effectively prevent acid precipitation in the area, by neutralizing the acids. The bivariate plots and ratios between $\left(\mathrm{NO}_{3}+\mathrm{Cl}\right)$ and $\left(\mathrm{SO}_{4}\right)$ showed that the acidic factor in significantly influenced by $\mathrm{HNO}_{3}$ and $\mathrm{HCL}$, rather than $\mathrm{H}_{2} \mathrm{SO}_{4}$. Whereas similar studies between $\left(\mathrm{NH}_{4}+\mathrm{Ca}\right)$ and $\left(\mathrm{NO}_{3}+\mathrm{SO}_{4}\right)$, showed that $\mathrm{NH}_{4}$ and $\mathrm{Ca}$ were dominating factors in prevention of acid rain over Asansol. The very high $\mathrm{NH}_{4}$ concentration can be attributed to bacterial decaying of organic matter like cow dung, etc. It can be said the alkaline components, influenced mostly by the natural process are neutralizing the acidic components, generated from manmade sources, effectively.

\section{ACKNOWLEDGMENTS}

The author would like to thank the principal and R. D. Wing, Department of Environment and Water Management, B. B. College, Asansol for providing financial and other support to carry out the research project. The author is also grateful to the reviewers for their valuable comments and suggestions.

\section{REFERENCES}

Anjaneyulu, Y., (2002). Textbook of air pollution and control technologies. Allied Publishers Private Limited. Mumbai, 91-217.

APHA. (1998). Standard Methods for Examination of Water and Waste-Water. 20th Ed. American Public Health Association, NY, Washington, D.C.

Balachandran, S.; Khillare, P. S., (2001). Occurrence of acid rain over Delhi. Environ. Moni. Assess. 71(2). 165-176.

Banerjee, D.; Agarwalla, N. L., (2005). Analysis of air quality in Asansol city. Environ. Pollut. Control J., 8 (6), 54 - 60.

Clarke, A. G.; Radojevic, M., (1987). Oxidation of $\mathrm{SO}_{2}$ in rainwater and its role in acid rain chemistry. Atmos. Environ. 21 (5) $1115-1123$

Granat, L.; Das, S. N.; Tharkur, R. S.; Rodhe, H., (2001). Atmospheric deposition in a rural area in India - net and potential acidity. Water Air Soil Pollut., 130 (1-4), 469-474 Khemani, L. T.; Momin, G. A.; Naik, M. S.; Rao, P. S. P.; Kumar, R.; Ramamurthy, B. V., (1985). Impact of alkaline particulates on $\mathrm{pH}$ of rain water in India. Water Air Soil Pollut., 24 (1), 365-376.

Khemani, L. T.; Momin, G. A.; Rao, P. S. P.; Pillai, A. G.; Safai, P. D.; Mohan, K.; Rao, M. G., (1994). Atmospheric pollutants and their influence on acidification of rain water at an industrial location on the west coast of India. Atmos. Environ., 28 (1), 3145-3154. 
Khemani, L. T.; Momin, G. A.; Rao, P. S. P.; Safai, P. D.; Singh, G.; Kapoor, R. K., (1989). Spread of acid rain in India. Atmos. Environ., 23(1), 757-762.

Kulshrestha, U. C.; Kulshrestha, M. J.; Sekhar, R.; Sastry, G. S. R.; Vairamani, M., (2003). Chemical characteristics of rainwater at an urban site of south-central India. Atmos. Environ., 37 (1), 3019-3026.

Kulshrestha, U. C.; Saxena, A.; Kumar, N.; Kumari, K. M.; Srivastava, S. S., (1995). Wet and bulk deposition study at New Delhi (India). Water Air Soil Pollut., 8 (1), 2137-2142.

Kulshresthaa, U. C.; Sarkara, A. K.; Srivastavab S. S.; Parashar, D. C., (1996). Investigation into atmospheric deposition through precipitation studies at New Delhi (India). Atmos. Environ., 30 (24), 4149-4154.

Kumar, R.; Rani, A.; Singh, S. P.; Kumari, K. M.; Srivastava, S. S., (2002). A long term study on chemical composition of rainwater at Dayalbagh, a suburban site of semi arid region, J. Atmos. Chem. 41 (1), 265-279.

Mahadevan, T. N.; Meenakshy, V.; Sathe, A. V., (1984). Some observations on chemical composition of precipitation in an industrial area and its use in air quality assessment. Mausam. 35 (1), 87-91.

Mahadevan, T. N.; Negi, B. S.; Meenakshy, V., (1989). Measurement of elemental composition of aerosol matter and precipitation from a remote background site in India. Atmos. Environ., 23 (1), 869-874.

Masamichi, T.; Masaki, K.; Kazuhiro, I., (2005). Precipitation chemistry of the Japanese forest area during the rainy season - Distribution and changes in precipitation chemistry during the 1990s. Bulletin of the Forestry and Forest Products Research Institute. 4 (1), 1-38.

Mphepya, J. N.; Pienaar, J. J.; Lacaux, C. G.; Held, G.; Turner, C. R., (2004). Precipitation chemistry in semi-arid areas of southern Africa: A case study of a rural and an industrial site. J. Atmos. Chem., 47 (1), 1-24.

Mukhopadhyay, B.; Datar, S. V.; Srivastava, H. N., (1992). Precipitation chemistry over the Indian region. Mausam, 43 (1), 249-258.

Naik, M. S.; Khemani, L. T.; Momin, C. A.; Rao, P. S. P., (1988). Measurement of $\mathrm{pH}$ and chemical analysis of rain water in rural area in India. Acta Math. Appl. Sin., 2 (1), 91100.

Naik, M. S.; Momin1, G. A.; Pillai, A. G.; Safai1, P. D.; Rao, P. S. P.; Khemani, L. T., (1985). Precipitation chemistry at
Sinhagad-a hill station in India. Water Air Soil Pollut., 85 (4), 2161-2166

Naik, M. S.; Momin, G. A.; Rao, P. S. P., Safai, P. D.; Ali, K., (2002). Chemical composition of rainwater around an industrial region in Mumbai. Curr. Sci., 82 (9), 1131-1137.

Parashar, D. C.; Kulshrestha, U. C.; Jain, M., (2001). Precipitation chemistry and aerosols studies in India. Environ. Monit. Assess., 66 (1), 47-61.

Pillai, A. G.; Naik, M. S.; Momin, G. A.; Rao, P. S. P.; Safai, P. D.; Ali, K.; Rodhe, H.; Granat, L. (2001). Studies of wet deposition and dustfall at Pune, India. Water Air Soil Pollut., 130 (1), 475-480.

Primerano, P.; Di Pasquate, S.; Mavilia, L.; Corigliano, F., (1998). Sources of strong acidity in the atmosphere. Atmos. Environ., 32 (1), 225-230.

Rao, P. S. P.; Momin, G. A.; Safai, P. D.; Pillai, A. G.; Khemani, L. T., (1995). Rain water and throughfall chemistry in the silent valley forest in south India. Atmos. Environ., 29 (16), 2025-2029.

Satsangi, G. S.; Lakhani, A.; Khare, P.; Singh, S. P. Kumari, K. M.; Srivastava, S. S., (1998). Composition of rain water at a semi-arid rural site in India. Atmos. Environ., 32 (21), 37833793.

Saxena, A.; Kulshrestha, U. C.; Kumar, N.; Kumari, K. M.; Srivastava, S. S., (1996). Characterization of precipitation at Agra. Atmos. Environ., 30 (20), 3405-3412.

Shrestha, A. B.; Wake, C. P.; Dibb, J. E.; Whitlow, S. I., (2002). Aerosol and precipitation chemistry at a remote Himalayan site in Nepal. Aerosol Sci. Tech., 36 (4), 441-456.

Singh, A. K.; Mondal, G. C.; Kumar, S.; Singh, K. K.; Kamal, K. P.; Sinha, A., (2007). Precipitation chemistry and occurrence of acid rain over Dhnabad, coal city of India. Environ. Monit. Assess., 125 (1), 99-110.

Srinivas, B.; Kumar, M. R.; Rao, P. S. P., (1999). A study on the chemistry of rain water in and around Hyderabad and Secunderabad, Indian J. Environ. Prot., 21 (3), 210-213.

Tiwari, S.; Pandey, A. K.; Momin, G. A.; Rao, P. S. P.; Safai, P. D.; Chate, D. M.; Ali, K., (2004). Chemical composition of precipitation in a rural environment at Ballia (UP), India. Indian J. Air Pollut. Cont., 4 (1), 33-39.

Williams, P. T.; Radojevic, M.; Clarke, A. G., (1988). Dissolution of trace metals from particles of industrial origin and its influence on the composition of rainwater. Atmos. Environ., 22 (7), 1433-1442.

\section{AUTHOR (S) BIOSKETCHES}

Banerjee, D., Ph.D., Department of Environment and Water Management, Banwarilal Bhalotia College, Asansol, West Bengal, India. Email: profdibyendu@rediffmail.com

This article should be referenced as follows:
Banerjee, D., (2008). Study of precipitation chemistry over an industrial city. Int. J. Environ. Sci. Tech., 5 (3),
331-338.

